\author{
Agustina Bidarti ${ }^{*}$, Dwidjono Hadi Darwanto ${ }^{2)}$, Slamet Hartono ${ }^{2)}$, \\ Jamhari2) \\ 1)Faculty of Agriculture, Universitas Sriwijaya Palembang \\ 2) Faculty of Agriculture, Universitas Gadjah Mada Yogyakarta \\ *)Email korespondensi: agustinabidarti@unsri.ac.id
}

AGRARIS: Journal of Agribusiness and Rural Develpoment Research

Vol. 5 No. 1 Januari-Juni 2019

\section{Supplier Structure and Performance Evaluation of Supplier Network Phase Rice Supply Chain Management in South Sumatra}

DOI: http://dx.doi.org/10.18196/agr.5171

\begin{abstract}
This study aims to identify the mapping, measure performance, and analyze problems in the structure of rice supply chain management on the supplier network phase in South Sumatra. Afterward, the result of this study is used as the basic consideration to improve the rice supply chain performance on indicators that have problems. Data collection was conducted by direct interview, questionnaire, and observation. This study used descriptive qualitative and several analysis tools as the data such as Supply Chain Operation Reference Model (SCOR), Analytical Hierarchy Process (AHP), Objective Matrix (OMAX) and Traffic Light System (TLS). According to the rice supply chain mapping on supplier network phase, there are three rice supply chains. Based on the interview, the farmers' main problem as the main producers of the rice supply chain in South Sumatra is the limitation of unhusked rice price information in harvesting in the financial flow of rice supply chain. Based on the weighting result by OMAX scoring system, the total index value is 7.28 , or in the yellow category which means that the performance of LICM rice- industry company in South Sumatra has not achieved the expected performance in terms of rice supply chain even though the result is close to the pre-determined target.
\end{abstract}

\author{
Keywords: Rice, Suppliers Structure, Performance Evaluation, Supply Chain \\ Management.
}

\section{INTRODUCTION}

In general, the related activities in the supply chain management are divided into four stages, namely: activities to get raw materials (procurement), activities to plan production and inventory (planning and control), production activities (manufacturing, shipping activities (distribution). (Pujawan, 2005; Sarmah et al., 2005; Adiyatna \& Hasibuan, 2015). In addition, there are three other phases in supply chain management, There are three phases in rice supply chain management, namely supplier network, integrated enterprise, dan distributive network. (Indrajit \& Richardus, 2005; Chopra \& Meindl, 2001; Kotler, 2003) These phases are similar to another phase according to Anatan \& Ellitan (2008) namely upstream supply chain, dan downstream supply chain. Supplier network phase is very important and equal to the next two phases for the rice industry. Good practices in supply chain management are needed in the development of the rice industry in South Sumatra.

Rice is the main source of calories for Indonesians. Therefore, nowadays, rice becomes a substantial part as consumption of calories reaching $54.3 \%$. It means that more than half of the amount of calories consumption comes from rice. According to Widodo \& Wulandari (2016), the high population growth rate in Indonesia reaching 230 million is directly proportional to the increasing demand for food. South Sumatra proclaims itself as one of the national food granary provinces. However, not all the areas in South Sumatra are rice producers. Therefore, the rice supply chain management as an materials to semi-finished products and final products, as well as distribution is important in South Sumatra. 
Supply Chain Operation Reference (SCOR) method is a reference model of supply chain operation. This study is based on Sidarto (2008) research on the measurement of supply chain management activities by combining SCOR and POA including cost, time, capacity, productivity, utility, outcome, reliability, responsiveness, flexibility, cost, and asset. Meanwhile, Ervil (2010) conducted study on the design system of performance measurement by developing a balanced scorecard model that produces supply chain performance indicator derived from company performance indicator. Both studies produce an overview of the company's internal condition in the best class position.

According to Mathuramaytha (2011), collaboration and integration of the supply chain can facilitate cooperation among institutions to increase competitive advantages. In addition, Susanawati et al. (2017) declare that many players involved in the supply chain can affect less than good performance because each of the players has their own level of importance, thus raising a number of issues about disproportionate distribution of risks among players.

Different from in South Sumatra, based on preliminary observations, it shows that rice procurement practices in rice-industry companies in South Sumatra often experience some problems on the fulfillment of raw materials by suppliers. Based on the background, it is necessary to conduct a study related to the structure pattern and performance of rice supply chain management on supplier network phase in South Sumatra as well as the recommendations in improving the supply chain performance.

Therefore, this study aims to: 1$)$. Describe the rice supply chain mapping at the supplier network stage in South Sumatra with descriptive method. 2). Evaluating rice supply chain performance at the supplier network stage in South Sumatra with SCOR analysis. SCOR is used to determine the weights of each criterion and subcriteria. 3). And evaluate the relationship of rice supply chain performance at the supplier network stage in South Sumatra with Objective Matrix (OMAX) and Traffic Light System (TLS) analysis. OMAX is a method that observes measurement matrix from the existing performance indicators by consolidating the matrix into a single measure. This model relates directly to all conditions to measure its work performance and used to evaluate the performance of suppliers. Evaluating supply chain rice at suppliers network stage performance used for providing some improvement recommendations for the enterprise and rice suppliers.

\section{METHODS}

This research employs descriptive and quantitative approaches. This research report was arranged in four stages: introduction, data collection and processing, analysis and discussion, and conclusion and suggestion. This research is the initial stage of selecting and determining the sample. Determination of the sample is done in two stages, determining the company and selecting respondents.

For the selected company carried out for examines the performance of each supply chain involved in the rice supply chain management on supplier network phase in South Sumatra. In order to determine the best performance, benchmarking of rice-industry companies in South Sumatra is conducted.

TABLE 1. RICE-INDUSTRY COMPANIES IN SOUTH SUMATRA

\begin{tabular}{lllc}
\hline No & \multicolumn{1}{c}{ Companies } & \multicolumn{1}{c}{ Company's address } & $\begin{array}{c}\text { Production } \\
\text { Capasity/Near }\end{array}$ \\
\hline 1 & $\begin{array}{l}\text { PT. Karya Jaya Mandiri } \\
\text { Perkasa }\end{array}$ & $\begin{array}{l}\text { Muara Kelingi RT 10, Karya Jaya, } \\
\text { Kertapati }\end{array}$ & 20,000 ton \\
2 & CV. Sukses Karya Mandiri & $\begin{array}{l}\text { Jalan Brigiend Yusuf No. 22 RT } \\
\text { 23 Musi II, Karya Jaya, Kertapati }\end{array}$ & 13,600 ton \\
3 & CV Lintas Indo Comoditi & $\begin{array}{l}\text { Jalan Mayjen Yusuf Singadikane } \\
\text { RT 01 RW 01 Musi II, Keramasan, }\end{array}$ & \\
& Mandiri & Kertapati & \\
& Jalan Ir. Sutami RT 22 Sei & 16,000 ton \\
4 & PD Piramid Sembada & Selincah, Kalidoni & \\
& &
\end{tabular}

Sources: Secondary Data Department of Industry and Commerce of Palembang City (2016)

According to the data, benchmarking of the companies which are selected as research sample used multistage. The sample selection in the supply chain mapping was conducted in two stages, according to the supplier network phase.

First, stage 1 is to determine the starting point of the rice supply chain in South Sumatra. By using purposive sampling method, CV Lintas Indo 
Comoditi Mandiri (CV LICM), a rice-industry company was chosen as the sample. The selection of rice-industry company is under the consideration of rice packaging products because of secondary processing product which made from the raw material product of South Sumatra areas OKI, OKUT, and Banyuasin Regency. Furthermore, CV LICM is an active agroindustry and the company will be measured for its performance.

Second, stage II is the determination of institutions related to the supply chain. After the company was selected as the starting point of the supply chain, the snowball technique was used to select rare characteristic unit and additional units shown by previous respondents. (Sarwono, 2006) This means that the determination of institutions involved in a flow of rice supply chain in South Sumatra can be known according to the information provided by other institutions.

Based on company data, there are three main regions supplying the company's raw materials. The three regions are OKI Regency, OKUT Regency, Banyuasin Regency, and Palembang City. In the three regions, samples were selected with snowball techniques such as stage II above. So that in each of these three regions 30 samples were obtained, consisting of 10 farmers, 10 village collector traders, and 10 rice mills owner. From each district there are 30 samples and plus 10 samples of provincial upperclass traders in the city of Palembang, based on simple random sampling, so the number of samples in this study were 100 samples.

The data was obtained through interviews, questionnaire, and related enterprise documents. The documents consist of primary data and secondary data. Primary data which are the data on suppliers performance evaluation criteria and subcriteria, level of necessity of each criterion and subcriteria, and the performance evaluation of suppliers. Secondary data is data regarding company profile, rice production process, and suppliers performance achievements.

The procedures of data processing in this research were started with developing linkage models through the Analytical Hierarchy Process (AHP). The criteria and subcriteria is determined as well as the linkage among criteria and sub-criteria that will be used in modeling AHP. (Balubaid \& Alamoudi, 2015) Secondly, establishing a paired comparison matrix. Then it followed by calculating the elements' weight which is obtained by normalizing paired comparison matrix and counting up (sum) the elements in one column. After knowing the value of elements weight, continued to calculate consistency ratio. The next step is developing supermatrix that consists of three stages such as unweighted supermatrix, weighted supermatrix, and limiting supermatrix. Then, Scoring System with OMAX method was evaluating rice suppliers performance by using TLS. TLS was used to find out whether the performance indicator needs improvement or not. For analysis and discussion stage would consist of analysis and discussion of data processing results. For the analysis is conducted at the necessary level of supplier performance evaluation criteria and subcriteria and also the improvement recommendations for the enterprise and suppliers. For conclusion and suggestion stage consist of the research conclusions obtained from the result of data collection and processing, result in analysis and discussion in response to the determined research objectives.

In order to analyze the map of rice supply chain network on supplier phase, this study used the descriptive analysis method. While the process of measuring the performance of rice supply chain management was based on the SCOR, AHP, OMAX and TLS method. The SCOR method was used to measure the performance of supply chain management, especially on the supplier phase that requires performance attribute criteria. SCOR, AHP, OMAX method and TLS are feasible tools to measure the performance achievement of suppliers. (Sukendar et al., 2018; Akyus \& Erkan, 2010; Van de Vorst, 2006).

\section{RESULTS AND DISCUSSIONS MAPPING OF SUPPLY CHAIN STRUCTURE ON SUPPLIER CHAIN NETWORK LEVEL}

Based on the data of the interview, the mechanism of seeking suppliers is conducted by opening tenders to find qualified suppliers. The CV 
Lintas Indo Comoditi Mandiri (CV LICM) policy in the tender selection process has selected some suppliers by using this approach which can reduce the risk that occurs when relying on too much supply on just one supplier. Currently, in the company's records, CV LICM has 23 suppliers who work under the contract system. All the suppliers are trading companies in South Sumatra.

Based on the above data on rice suppliers, it is necessary to see the behavior of rice supply system in CV LICM. According to the observation, there are three network flows of the rice supply chain on supplier network phase in South Sumatra.

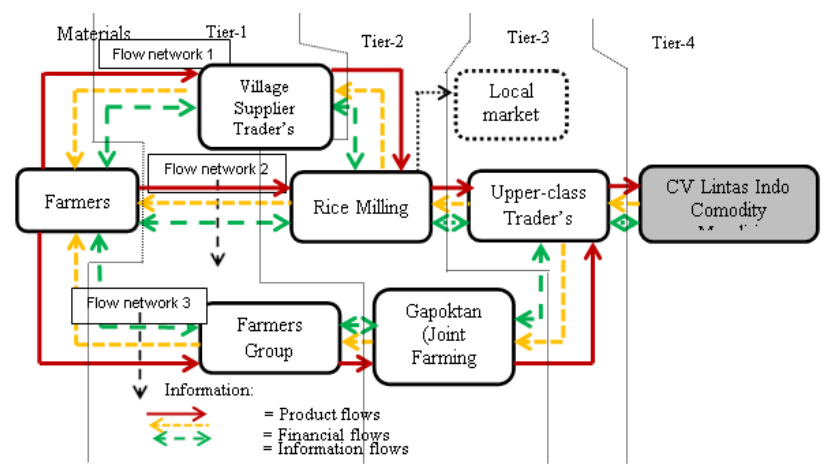

FIGURE 1. RICE SUPPLY CHAIN STRUCTURE ON SUPPLIER NETWORK PHASE IN SOUTH SUMATRA

On the first flow, farmers sell unhusked rice to village suppliers (45.56\%). The village suppliers buy rice from the farmers in the form of dried unhusked rice (the crop yield/GKP) to be milled into dry unhusked rice $(\mathrm{GKG})$ sold to the rice mills. The village suppliers are usually individual traders working for the rice mills. According to the questionnaire, this network flow is mostly selected by the farmers in OKUT (76.67\%), OKI (40.00\%) and Banyuasin Regency (20.00\%). Farmers, especially in OKUT because it is easier to get cash. The village suppliers buy crops to the farmers by using slash system. Even though it is less transparent, in which the farmers sell their crops in the rice fields without knowing the amount of unhusked rice production from the harvest result. The farmers do not harvest because it is conducted by the suppliers after they agree on the purchase price. If on average, the sale price of unhusked rice received by the farmers by using slash system is IDR $4.220 / \mathrm{Kg}$ for dried unhusked rice. They accept this system because they need the cash directly.

The second pattern of this supplier network phase is the farmers $(28.89 \%)$ distribute their crops to the rice millers in the form of dried unhusked rice or dry milled rice. After going through the milling process, rice is temporarily packed by the rice millers. Afterward, it is distributed to large-scale traders in districts and cities. Furthermore, it is distributed to CV LICM company to be processed further. This flow network was mostly chosen by OKI $(53.33 \%)$, then followed by OKUT (20.00\%) and Banyuasin (13.33\%). The farmers' choice to sell their crops directly to the rice miller with kilogram system is caused by several things. First, there is a new trend in which the rice millers also build storage and drying rice place near the rice fields. It makes it easier for farmers to sell their crops. Second, the price received by the farmers in selling their unhusked rice to the rice mill is higher compared to the slash system which generally conducted in the second supply chain network in South Sumatra. The selling price to rice mill is IDR 4.500 dry unhusked rice crops.

On the third flow, the farmers $(25.56 \%)$ sell their crops to farmer groups in the form of dry unhusked rice. Based on the questionnaire, this choice is selected by farmers in Banyuasin Regency (66.67\%), OKI (6.67\%) and OKUT (3.33\%). The interview result shows lack of treatment of the third flow especially in OKI and OKUT Regency. It proves that both regencies are less involved in Village Unit Cooperatives (KUD) in the rice supply chain flow.

In this case, it is caused by several things. First, KUD rarely takes a role in the trade sector of unhusked rice and rice commodities in the supply chain in South Sumatra. The low role of farmer institutions like this is also shown by the study of Nuraini et al. (2016) and Triyono et al. (2016) where patterns of a structure of farmer relations in institutional tendencies are characterized by the absence of functional organizational relationships between each level of business. Therefore, this is in line with Surono (1998) opinion, that KUD in Indonesia has little role in the marketing sector of unhusked rice and rice commodities. Second, there is 
a hidden role where KUD acts as rice millers such as KUD Tugu Muda in Tugumulyo Village, OKI or KUD Telang Makmur in Muara Telang, Banyuasin. Third, KUD provides a technical role which covers cultivation and distribution of agricultural production facilities. The low role of KUD in the three research locations similarity with Sidik and Purnomo (1991) research in Karawang. They state that the tendency of unhusked rice higher price in the market affects less involvement of KUD and the BULOG (Food Logistic Agency). It makes KUD and BULOG reduce their role in purchasing unhusked rice and rice to the farmers, including in South Sumatra.

According to Suhardedi et al. (2017) study, in order to increase the profit and rice farming competitiveness, the government should implement subsidy, output price protection, infrastructure, and productivity improvement. However, the government intervention is also needed in helping the farmers to overcome their post-harvest problems. There should be an evaluation and reshuffle regarding to the rice supply chain on this phase by strengthening the institutions developed by KUD and BP3K (Extension Centers for Agricultural, Fisheries, and Forestry) in sub-district level and agricultural service in regency or province.

The farmers in these three districts tend easier to sell the harvest-unhusked rice other than storeunhusked rice. There are two reasons for farmers' difficulties in producing unhusked rice showed in the interview's result. First, the difficulty in managing indirect sales because direct sales dominate the supply chain. Second, there is a farmers' urgent need so they prefer to sell their crops directly. Third, lack of storage facility and sufficient unhusked rice drying in farmers' house. Those reasons affect the farmers' lower bargaining position.

Those reasons also cause the farmers still face some problems in marketing the crops on flow map of rice supply chain management on suppliers network phase in South Sumatra. In addition, they also have a limitation in understanding price information when harvesting. In fact, according to Indardi (2016) study, in the information era, the communication aspect is believed to be one of the important factors for the empowerment of farming communities. However, ironically, the farmers have a limitation in product market information.

\section{THE EVALUATION OF RICE SUPPLY CHAIN ON SUPPLIER NETWORK PHASE IN SOUTH SUMATRA}

The evaluation of the rice supply chain on supplier network phase in South Sumatra is very important to be conducted. It is because of the raw material procurement system in the rice supply chain which is required by Tier-3. CV LICM as the final network that will produce rice from the farmers. This evaluation will also be linked to how the rice supply chain works from farmers, village suppliers, rice mills, large-scale traders and finally to companies.

The initial stage of evaluation performance of the supply chain is conducted by submitting an initial questionnaire consisting of 46 indicators of performance according to Key Performance Indicators (KPI). The questionnaire was given to the management of CV LICM to identify the problems and the company's condition in supply chain management for validation. The purpose of this rice supply chain on suppliers network performance assessment is to assess the condition of an existing supply chain. This assessment can determine whether good or not good the activity process of rice supply chain on supplier network phase.

In the first calculation, perspective weighting is conducted on level 1 based on five SCOR perspective ratings, weighted results such as table 2 .

TABLE 2. THE RESULT OF WEIGHTED PERSPECTIVE LEVEL-1

\begin{tabular}{lcccc}
\hline Perspective & $\begin{array}{c}\text { Weight } \\
\text { (Eigenvalue) }\end{array}$ & Total & $\begin{array}{c}\text { Inconsistency } \\
\text { Ratio }\end{array}$ & Priority \\
\hline Plan & 0.453 & & $\lambda_{\max }=3.250$ & 1 \\
Source & 0.248 & 1 & $\mathrm{Cl}=0.092$ & 2 \\
Make & 0.156 & 1 & $\mathrm{RI}=1.188$ & 3 \\
Deliver & 0.052 & & $\mathrm{CR}=0.07$ & 5 \\
Return & 0.090 & & & \\
\hline
\end{tabular}

Sources: Primary Data (2017)

It is found that the weighting of five SCOR perspective ratings shows the inconsistency ratio at the weight of 0.07 . The weight is accepted because it has fulfilled the maximum limit of 0.1 , after conducting 
data analysis and processing on level-1, the next is on level-2. The result of level-2 weighted can be seen in table 3 below.

TABLE 3. THE RESULT OF WEIGHTED DIMENSION LEVEL-2

\begin{tabular}{|c|c|c|c|}
\hline Perspective & Dimension & Weight & Priority \\
\hline \multirow[t]{6}{*}{ Plan } & Reliability & 0.524 & 1 \\
\hline & Responsiveness & 0.233 & 2 \\
\hline & Flexibility & 0.079 & 4 \\
\hline & Asset & 0.164 & 3 \\
\hline & Total & 1 & \\
\hline & Inconsistency Ratio & 0.14 & \\
\hline \multirow[t]{7}{*}{ Source } & Reliability & 0.391 & 1 \\
\hline & Responsiveness & 0.254 & 2 \\
\hline & Flexibility & 0.146 & 4 \\
\hline & Cost & 0.052 & 5 \\
\hline & Asset & 0.157 & 3 \\
\hline & Total & 1 & \\
\hline & Inconsistency Ratio & 0.32 & \\
\hline \multirow[t]{7}{*}{ Make } & Reliability & 0.451 & 1 \\
\hline & Responsiveness & 0.250 & 2 \\
\hline & Flexibility & 0.148 & 3 \\
\hline & Cost & 0.068 & 5 \\
\hline & Asset & 0.084 & 4 \\
\hline & Total & 1 & \\
\hline & Inconsistency Ratio & 0.19 & \\
\hline \multirow[t]{3}{*}{ Deliver } & Reliability & 1 & 1 \\
\hline & Total & 1 & \\
\hline & Inconsistency Ratio & 0.03 & \\
\hline \multirow[t]{4}{*}{ Return } & Reliability & 0.600 & 1 \\
\hline & Responsiveness & 0.400 & 2 \\
\hline & Total & 1 & \\
\hline & Inconsistency Ratio & 0 & \\
\hline
\end{tabular}

Based on table 3, it is found that the overall weighting result of each dimension has the weight value under 0.1 . This shows that the weight value is still accepted because it is under the maximum limit of the inconsistency ratio of 0.1. After conducting data analysis and processing on level-2, the next is on level-3. The result of level-3 weighted can be seen in table 4 below.

Based on table 4 for the level-3, it is found that the overall indicator of KPI has the weight value under 0.1. This means that the weight value is still acceptable because the category is under the maximum limit of the inconsistency ratio of 0.1.
TABLE 4. THE RESULT OF WEIGHTED KPI LEVEL-3

\begin{tabular}{|c|c|c|c|c|c|}
\hline Perspective & Dimension & KPI & Weight & $\begin{array}{c}\text { Inconsistency } \\
\text { Ratio } \\
\end{array}$ & Priority \\
\hline \multirow[t]{9}{*}{ Plan } & Reliability & PR-1 & 0.830 & \multirow{2}{*}{0} & 1 \\
\hline & & PR-2 & 0.170 & & 2 \\
\hline & Responsibility & PRe-1 & 0.830 & \multirow{3}{*}{0} & 1 \\
\hline & & PRe-2 & 0.170 & & 2 \\
\hline & Flexibility & PF-1 & 0.544 & & 1 \\
\hline & & PF-2 & 0.265 & \multirow{3}{*}{0.13} & 2 \\
\hline & & PF-3 & 0.129 & & 3 \\
\hline & & PF-4 & 0.062 & & 4 \\
\hline & Asset & PA-1 & 1 & 0 & 1 \\
\hline \multirow[t]{8}{*}{ Sources } & Reliability & SR-1 & 0.634 & \multirow{3}{*}{0.14} & 1 \\
\hline & & SR-2 & 0.260 & & 3 \\
\hline & & SR-3 & 0.106 & & 4 \\
\hline & Responsibility & SRe-1 & 1 & 0 & 1 \\
\hline & Flexibility & SF-1 & 1 & 0 & 1 \\
\hline & Cost & SC-1 & 1 & 0 & 1 \\
\hline & & $S A-1$ & 0.830 & \multirow{2}{*}{0} & 1 \\
\hline & Asset & $S A-2$ & 0.170 & & 2 \\
\hline \multirow[t]{11}{*}{ Make } & Reliability & MR-1 & 0.800 & \multirow{2}{*}{0} & 1 \\
\hline & & MR-2 & 0.200 & & 2 \\
\hline & Responsibility & MRe-1 & 0.750 & \multirow{2}{*}{0.75} & 1 \\
\hline & & MRe-2 & 0.250 & & 2 \\
\hline & Flexibility & MF-1 & 1 & 0 & 1 \\
\hline & Cost & MC-1 & 1 & \multirow[t]{3}{*}{0} & 1 \\
\hline & \multirow[t]{5}{*}{ Asset } & MA-1 & 0.447 & & 1 \\
\hline & & MA-2 & 0.274 & & 2 \\
\hline & & MA-3 & 0.147 & \multirow[t]{3}{*}{0.08} & 3 \\
\hline & & MA-4 & 0.093 & & 4 \\
\hline & & MA-5 & 0.039 & & 5 \\
\hline \multirow[t]{8}{*}{ Delivery } & \multirow[t]{8}{*}{ Reliability } & DR-1 & 0.328 & \multirow{8}{*}{0.08} & 1 \\
\hline & & DR-2 & 0.206 & & 2 \\
\hline & & DR-3 & 0.148 & & 3 \\
\hline & & DR-4 & 0.122 & & 4 \\
\hline & & DR-5 & 0.086 & & 5 \\
\hline & & DR-6 & 0.052 & & 6 \\
\hline & & DR-7 & 0.036 & & 7 \\
\hline & & DR-8 & 0.022 & & 8 \\
\hline \multirow[t]{9}{*}{ Return } & Reliability & RR-1 & 1 & 0 & \\
\hline & Responsibility & RRe-1 & 0.087 & \multirow{8}{*}{0.07} & 5 \\
\hline & & RRe-2 & 0.061 & & 6 \\
\hline & & RRe-3 & 0.041 & & 7 \\
\hline & & RRe-4 & 0.207 & & 2 \\
\hline & & RRe-5 & 0.166 & & 3 \\
\hline & & RRe-6 & 0.021 & & 8 \\
\hline & & RRe-7 & 0.118 & & 4 \\
\hline & & RRe-8 & 0.299 & & 1 \\
\hline
\end{tabular}

Sources: Primary Data (2017)

\section{OMAX ANALYSIS ON THE RELATIONSHIP PERFORMANCE OF COMPANY AND SUPPLIERS}

After conducting data analysis and processing on level-2, the next is on level-3. After analyzing and weighting SCOR and AHP, then calculated the scoring system by using OMAX. The OMAX scoring system for each SCOR plan perspective can be seen in Table 5: 
TABLE 5. SCORING SYSTEM OMAX FOR PERSPECTIVE PLAN CV LINTAS INDO COMODITY MANDIRI

\begin{tabular}{|c|c|c|c|c|c|c|c|c|c|c|c|}
\hline \multicolumn{2}{|l|}{ KPI. No. } & PR-1 & PR-2 & PRe-1 & PRe-2 & PF-1 & PF-2 & PF-3 & PF-4 & PA-1 & Criteria \\
\hline \multicolumn{2}{|l|}{ Performance } & 97.54 & 89.52 & 86.11 & 0.0110 & 99.00 & 1.208 & 0.043 & 98.33 & 99.17 & \\
\hline \multirow{11}{*}{$\begin{array}{l}\mathrm{L} \\
\mathrm{E} \\
\mathrm{V} \\
\mathrm{E} \\
\mathrm{L}\end{array}$} & 10 & 100.00 & 100.00 & 100.00 & 0.0150 & 100.00 & 1.250 & 0.050 & 100.00 & 100.00 & Very Good \\
\hline & 9 & 99.31 & 98.28 & 97.69 & 0.0144 & 99.44 & 1.206 & 0.048 & 98.94 & 99.51 & \multirow{4}{*}{ Good } \\
\hline & 8 & 98.62 & 96.56 & 95.37 & 0.0138 & 98.88 & 1.162 & 0.046 & 97.88 & 99.02 & \\
\hline & 7 & 97.93 & 94.84 & 93.06 & 0.0132 & 98.33 & 1.119 & 0.044 & 96.83 & 98.54 & \\
\hline & 6 & 97.24 & 93.12 & 90.74 & 0.0126 & 97.97 & 1.075 & 0.041 & 95.77 & 98.05 & \\
\hline & 5 & 96.56 & 91.40 & 88.43 & 0.0121 & 97.22 & 1.032 & 0.039 & 94.72 & 97.57 & \multirow{3}{*}{ Average } \\
\hline & 4 & 95.87 & 89.68 & 86.11 & 0.0115 & 96.66 & 0.988 & 0.036 & 93.66 & 97.08 & \\
\hline & 3 & 91.54 & 81.93 & 77.08 & 0.0099 & 92.50 & 0.742 & 0.030 & 87.75 & 92.81 & \\
\hline & 2 & 87.21 & 74.18 & 68.05 & 0.0083 & 88.33 & 0.496 & 0.023 & 81.83 & 88.54 & \multirow{2}{*}{ Poor } \\
\hline & 1 & 82.88 & 66.43 & 59.02 & 0.0067 & 84.17 & 0.251 & 0.017 & 75.92 & 84.27 & \\
\hline & 0 & 78.56 & 58.69 & 50.00 & 0.0050 & 80.00 & 0.005 & 0.010 & 70.00 & 80.00 & Very Poor \\
\hline Level & & 8 & 8 & 8 & 7 & 8 & 9 & 7 & 9 & 8 & \\
\hline Weight & & 0.830 & 0.170 & 0.830 & 0.170 & 0.544 & 0.265 & 0.129 & 0.062 & 1 & \\
\hline Value & & 6.640 & 1.360 & 6.640 & 1.190 & 4.352 & 2.385 & 0.903 & 0.558 & 8.000 & \\
\hline
\end{tabular}

Sources: Primary data (2017)

The OMAX scoring system value for plan perspective in CV LICM is $9 \mathrm{KPI}$. There are $7 \mathrm{KPI}$ which are in the green category (between level 8 and 9) and 2 KPI which are in the yellow category (in level
7). Because the achievement value is in accordance with the target and all are above the red category, then the KPI does not need to be repaired.

TABLE 6. SCORING SYSTEM OMAX FOR PERSPECTIVE SOURCES CV. LICM

\begin{tabular}{|c|c|c|c|c|c|c|c|c|c|c|}
\hline \multicolumn{2}{|c|}{ KPI. No. } & SR-1 & SR-2 & SR-3 & SRe-1 & SF-1 & SC-1 & SA-1 & SA-2 & Criteria \\
\hline \multicolumn{2}{|c|}{ Performance } & 94.79 & 98.66 & 97.27 & 90.85 & 17.43 & 22.39 & 23.59 & 0.015 & \\
\hline \multirow{11}{*}{$\begin{array}{l}\mathrm{L} \\
\mathrm{E} \\
\mathrm{V}\end{array}$} & 10 & 98.73 & 100.00 & 99.99 & 96.05 & 21.43 & 24.90 & 28.88 & 0.020 & Very Good \\
\hline & 9 & 97.35 & 99.38 & 99.38 & 94.71 & 20.76 & 24.49 & 27.84 & 0.019 & \multirow{3}{*}{ Good } \\
\hline & 8 & 95.80 & 98.75 & 98.77 & 93.37 & 20.09 & 24.08 & 26.80 & 0.018 & \\
\hline & 7 & 95.05 & 98.13 & 98.16 & 92.03 & 19.42 & 23.68 & 25.76 & 0.017 & \\
\hline & 6 & 94.38 & 97.50 & 97.56 & 90.69 & 18.76 & 23.28 & 24.71 & 0.016 & \multirow{4}{*}{ Average } \\
\hline & 5 & 93.88 & 96.88 & 96.95 & 89.35 & 18.09 & 22.87 & 23.67 & 0.015 & \\
\hline & 4 & 93.64 & 96.25 & 96.35 & 88.00 & 17.43 & 22.47 & 22.62 & 0.014 & \\
\hline & 3 & 91.93 & 89.69 & 95.22 & 84.81 & 15.99 & 21.54 & 21.21 & 0.012 & \\
\hline & 2 & 90.21 & 83.13 & 94.08 & 81.62 & 14.55 & 20.62 & 19.8 & 0.010 & \multirow{2}{*}{ Poor } \\
\hline & 1 & 88.50 & 76.57 & 92.95 & 78.44 & 13.11 & 19.70 & 18.4 & 0.008 & \\
\hline & 0 & 86.78 & 70.00 & 91.82 & 75.25 & 11.67 & 18.78 & 17.00 & 0.006 & Very Poor \\
\hline \multicolumn{2}{|c|}{ Level } & 7 & 8 & 6 & 6 & 4 & 4 & 5 & 5 & \\
\hline \multicolumn{2}{|c|}{ Weight } & 0.634 & 0.260 & 0.106 & 1 & 1 & 1 & 0.830 & 0.170 & \\
\hline \multicolumn{2}{|c|}{ Value } & 4.438 & 2.080 & 0.636 & 6 & 4 & 4 & 4.150 & 0.850 & \\
\hline
\end{tabular}

Sources: Primary Data (2017)

Based on table 6, the OMAX scoring system value for sources perspective in CV LICM are $8 \mathrm{KPI}$. There is only $1 \mathrm{KPI}$ which is in the green category (level 8 and 7). KPI is in the yellow category, ranging from 4 and 7 levels. From those result, all the KPI have fulfilled the target so the KPI does not need to be repaired. However, it is necessary to increase the performance for the KPI which are in the yellow category where it approaches the red category. 
TABLE 7. SCORING SYSTEM OMAX FOR PERSPECTIVE MAKE CV. LICM

\begin{tabular}{cccccccccccccc}
\hline KPI. No. & MR-1 & MR-2 & MRe-1 & MRe-2 & MF-1 & MC-1 & MA-1 & MA-2 & MA-3 & MA-4 & MA-5 & Criteria \\
\hline Performance & & 1.790 & 93.48 & 99.33 & 99.24 & 92.83 & 98.65 & 91.59 & 95.91 & 95.65 & 97.83 & 97.17 & \\
& 10 & 0.780 & 96.60 & 100.00 & 99.99 & 94.60 & 99.99 & 94.45 & 99.00 & 99.99 & 99.00 & 99.50 & Very Good \\
& 9 & 1.031 & 95.77 & 99.57 & 99.65 & 93.77 & 99,37 & 93.62 & 98.17 & 96.60 & 98.67 & 98.67 & \\
L & 8 & 1.282 & 94.97 & 99.14 & 99.31 & 92.97 & 98.74 & 92.82 & 97.37 & 96.21 & 98.34 & 97.87 & Good \\
E & 7 & 1.533 & 94.22 & 98.81 & 98.97 & 92.22 & 98.12 & 92.07 & 96.62 & 95.40 & 98.01 & 97.12 & \\
V & 6 & 1.784 & 93.55 & 98.34 & 98.63 & 91.55 & 97.49 & 91.40 & 95.95 & 95.15 & 97.67 & 96.45 & \\
E & 5 & 2.035 & 93.05 & 97.88 & 98.29 & 91.05 & 96.87 & 90.90 & 95.45 & 94.90 & 97.34 & 96.15 & \\
L & 4 & 2.285 & 92.65 & 97.41 & 97.94 & 91.20 & 96.24 & 90.16 & 93.70 & 94.65 & 97.00 & 96.00 & Average \\
& 3 & 3.130 & 90.86 & 94.31 & 95.70 & 87.95 & 92.43 & 88.15 & 91.53 & 93.24 & 95.75 & 94.63 & \\
& 2 & 3.975 & 89.07 & 91.21 & 93.46 & 84.70 & 88.62 & 86.14 & 89.35 & 91.82 & 94.50 & 94.55 & Poor \\
& 1 & 4.821 & 87.29 & 88.11 & 91.32 & 81.45 & 84.81 & 84.13 & 87.18 & 90.41 & 93.25 & 94.48 & \\
& 0 & 5.666 & 85.50 & 85.00 & 88.99 & 78.20 & 80.99 & 82.12 & 85.00 & 88.99 & 92.00 & 90.50 & Very Poor \\
\hline Level & 6 & 6 & 8 & 8 & 8 & 8 & 6 & 6 & 7 & 6 & 7 & \\
Weight & 0.800 & 0.200 & 0.750 & 0.250 & 1 & 1 & 0.447 & 0.274 & 0.147 & 0.093 & 0.039 &
\end{tabular}

The OMAX scoring system value for making perspective ratings in CV LICM are $11 \mathrm{KPI} .4 \mathrm{KPI}$ are in the green category while the rest is in the yellow category. The KPI in the yellow category needs to be remedied to improve performance.

TABLE 8. SCORING SYSTEM OMAX FOR PERSPECTIVE DELIVERY CV. LICM

\begin{tabular}{ccccccccccc}
\hline \multicolumn{2}{c}{ KPI. No. } & DR-1 & DR-2 & DR-3 & DR-4 & DR-5 & DR-6 & DR-7 & DR-8 & Criteria \\
\hline \multicolumn{2}{c}{ Performance } & 98.05 & 96.26 & 95.93 & 94.83 & 97.26 & 95.16 & 97.02 & 0.031 & \\
& 10 & 100.00 & 98.15 & 98.33 & 96.13 & 99.01 & 95.50 & 98.18 & 0.034 & Very Good \\
& 9 & 99.17 & 97.32 & 97.50 & 95.60 & 98.18 & 96.03 & 97.35 & 0.033 & \\
L & 8 & 98.37 & 96.52 & 96.70 & 95.06 & 97.38 & 95.83 & 96.55 & 0.031 & Good \\
E & 7 & 97.62 & 95.77 & 95.95 & 94.52 & 96.63 & 95.29 & 95.80 & 0.030 & \\
V & 6 & 96.95 & 95.10 & 95.28 & 93.99 & 95.96 & 94.75 & 95.13 & 0.029 & \\
E & 5 & 96.45 & 94.60 & 94.78 & 93.46 & 95.46 & 94.21 & 94.63 & 0.027 & \\
L & 4 & 96.28 & 94.11 & 94.99 & 92.92 & 95.15 & 93.66 & 93.69 & 0.026 & Average \\
& 3 & 94.71 & 89.31 & 93.97 & 91.22 & 90.80 & 92.12 & 88.99 & 0.022 & \\
& 2 & 93.14 & 84.51 & 92.95 & 89.52 & 86.44 & 90.58 & 84.29 & 0.017 & Poor \\
& 1 & 93.69 & 79.71 & 91.93 & 87.82 & 82.09 & 89.04 & 79.60 & 0.013 & Very Poor \\
\hline & 0 & 92.15 & 74.90 & 90.90 & 86.12 & 77.73 & 86.12 & 74.90 & 0.010 & \\
\hline Level & & 8 & 8 & 7 & 8 & 8 & 7 & 9 & 8 & \\
Weight & 0.328 & 0.206 & 0.148 & 0.122 & 0.086 & 0.052 & 0.036 & 0.022 & \\
Value & 2.624 & 1.648 & 1.036 & 0.976 & 0.688 & 0.364 & 0.324 & 0.176 & \\
\hline
\end{tabular}

Sources: Primary Data (2017)

Moreover, the OMAX scoring system value for delivery perspective in CV LICM are 8 KPI. 6 KPI are in the green category while the rest are in the yellow category. All the KPI do not need to be repaired because it has met the target. 
TABLE 9 SCORING SYSTEM OMAX FOR PERSPECTIVE RETURN CV LICM

\begin{tabular}{|c|c|c|c|c|c|c|c|c|c|c|c|}
\hline \multicolumn{2}{|l|}{ KPI. No. } & RR-1 & RRe-1 & RRe-2 & RRe-3 & RRe-4 & RRe-5 & RRe-6 & RRe-7 & RRe-8 & Criteria \\
\hline \multicolumn{2}{|l|}{ Performance } & 4.32 & 95.50 & 99.00 & 98.33 & 94.16 & 95.58 & 96.58 & 0.011 & 0.07 & \multirow{3}{*}{ Very Good } \\
\hline \multirow{11}{*}{$\begin{array}{l}\mathrm{L} \\
\mathrm{E} \\
\mathrm{V} \\
\mathrm{E} \\
\mathrm{L}\end{array}$} & 10 & 4.00 & 96.50 & 100.00 & 100.00 & 100.00 & 100.00 & 100.00 & 100.00 & 0.03 & \\
\hline & 9 & 4.10 & 96.31 & 99.68 & 99.58 & 98.50 & 98.75 & 98.83 & 0.009 & 0.04 & \\
\hline & 8 & 4.20 & 95.11 & 99.36 & 99.16 & 97.00 & 97.50 & 97.66 & 0.010 & 0.05 & \multirow{2}{*}{ Good } \\
\hline & 7 & 4.30 & 95.17 & 99.04 & 98.74 & 96.50 & 96.25 & 96.50 & 0.011 & 0.06 & \\
\hline & 6 & 4.40 & 95.22 & 98.72 & 98.32 & 94.00 & 95.00 & 95.33 & 0.012 & 0.07 & \multirow{4}{*}{ Average } \\
\hline & 5 & 4.50 & 95.28 & 98.40 & 97.90 & 93.50 & 93.75 & 94.16 & 0.013 & 0.08 & \\
\hline & 4 & 4.60 & 95.33 & 98.08 & 96.80 & 92.50 & 92.50 & 93.00 & 0.014 & 0.10 & \\
\hline & 3 & 4.90 & 94.12 & 96.06 & 95.10 & 88.38 & 88.12 & 89.75 & 0.016 & 0.12 & \\
\hline & 2 & 5.20 & 91.58 & 94.04 & 93.40 & 86.25 & 83.75 & 86.50 & 0.018 & 0.13 & \multirow{2}{*}{ Poor } \\
\hline & 1 & 5.50 & 90.54 & 90.71 & 91.70 & 83.13 & 79.37 & 83.25 & 0.020 & 0.14 & \\
\hline & 0 & 5.70 & 90.50 & 90.00 & 90.00 & 80.00 & 75.00 & 80.00 & 0.021 & 0.16 & Very Poor \\
\hline \multicolumn{2}{|l|}{ Level } & 7 & 8 & 7 & 6 & 6 & 6 & 7 & 7 & 6 & \\
\hline \multicolumn{2}{|l|}{ Weight } & 1 & 0.087 & 0.061 & 0.041 & 0.207 & 0.166 & 0.021 & 0.118 & 0.299 & \\
\hline \multicolumn{2}{|l|}{ Value } & 7 & 0.696 & 0.427 & 0.246 & 1.242 & 0.996 & 0.147 & 0.826 & 1.794 & \\
\hline
\end{tabular}

Sources: Primary Data (2017)

Based on table 9, the OMAX scoring system value for sources return in CV LICM are $8 \mathrm{KPI}$. There is only $1 \mathrm{KPI}$ which is in the green category (level 8) and $8 \mathrm{KPI}$ which in the yellow category, but ranging from 6 and 7 levels. All the KPI do not need to be repaired because it has met the target.

Based on tables 5, 6, 7, 8, and 9 for OMAX analysis above, a perspective analysis is obtained which is the core process as shown in Figure 2. Figure 2 shows that the source perspective has a relatively small weight of 5,625, then the return and make perspectives have relatively equal weights and include small criteria, which has a weight of 6.66 and 6.90 . The source perspective needs to be increased in weight. The source perspective is considered important because the company always wants to maximize supplier capabilities. The source perspective is closely related to the return perspective in terms of standardization of raw materials from suppliers and a make perspective regarding the process of making raw materials into the company's main products. Therefore, improving performance in the perspective of the source for the company is very important. Therefore, improving performance on the source perspective, including the return perspective and make perspective for companies is very important in making rice products.

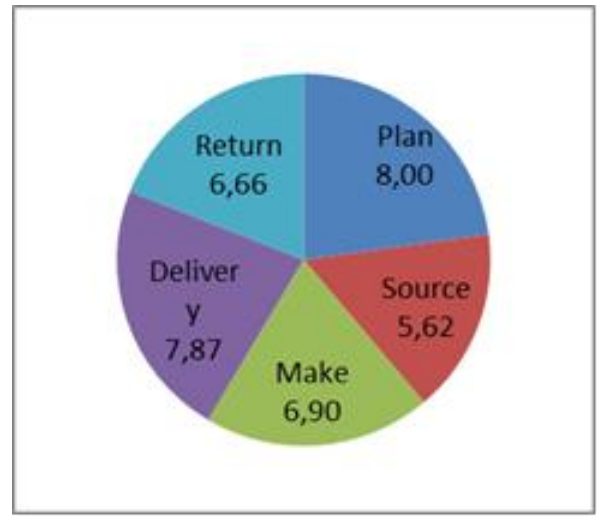

\section{FIGURE 2. PERSPECTIVE WEIGHTS COMPARISON OF SUPPLIERS PERFORMANCE EVALUATION}

Then, after analyzing the perspective, then based on the OMAX analysis above the performance assessment is carried out for dimensional subcriteria. Performance appraisal for the dimension subcriteria is shown in table 10 below. In essence, all the dimension sub-criteria are not at the red level (below level 3) which is a poor criterion and must be corrected immediately. The average dimension sub-criteria of the perspective performance are in green, which means that it is very good, and most of them are still in yellow, which means they are on the average criteria. 


\section{TABLE. 10. PERFORMANCE DIMENSIONS}

\begin{tabular}{|c|c|c|c|c|}
\hline \multicolumn{2}{|c|}{ Perspective Dimension Cod } & Performance indicator & \multirow{2}{*}{$\begin{array}{c}\text { Total } \\
2\end{array}$} & \multirow{2}{*}{$\frac{\text { Weights }}{7}$} \\
\hline Plan & PRe-2 & $\begin{array}{l}\text { Planning identifies the raw material } \\
\text { specifications }\end{array}$ & & \\
\hline \multirow{8}{*}{ Sources } & PF-4 & Planning to procure company rice products & \multirow{8}{*}{7} & 7 \\
\hline & SR-1 & Disability of raw materials from suppliers & & 7 \\
\hline & SR-3 & Reliability in the delivery of raw materials & & 6 \\
\hline & SRe-1 & Raw Material Lead Time & & 6 \\
\hline & SF-1 & Availability of raw materials from suppliers & & 4 \\
\hline & SC-1 & Cost of ordering raw materials from suppliers & & 4 \\
\hline & SA-1 & $\begin{array}{l}\text { Daily supply of raw materials for rice from } \\
\text { suppliers }\end{array}$ & & 5 \\
\hline & SA-2 & Payment of raw material for rice to suppliers & & 5 \\
\hline \multirow{7}{*}{ Make } & MR-1 & Errors in packing raw materials from suppliers & \multirow{6}{*}{7} & 6 \\
\hline & MR-2 & $\begin{array}{l}\text { Amount of defective raw material from } \\
\text { suppliers }\end{array}$ & & 6 \\
\hline & MA-1 & $\begin{array}{l}\text { The average length of life of the tool in the } \\
\text { company }\end{array}$ & & 6 \\
\hline & MA-2 & Monthly company needs & & 6 \\
\hline & MA-3 & Company inventory level data & & 7 \\
\hline & MA-4 & $\begin{array}{l}\text { Processed raw materials from suppliers to } \\
\text { products }\end{array}$ & & 6 \\
\hline & MA-5 & Processing data on raw materials and products & \multirow{9}{*}{8} & 7 \\
\hline \multirow{8}{*}{ Return } & RR-1 & Level of complaint to the supplier & & 7 \\
\hline & RRe-2 & Complaint report & & 7 \\
\hline & $\operatorname{RRe}-3$ & Checking damaged raw materials & & 6 \\
\hline & RRe-4 & Repair of damaged raw materials & & 6 \\
\hline & $\operatorname{RRe}-5$ & Created rules for each process & & 6 \\
\hline & RRe-6 & Checking raw material samples & & 7 \\
\hline & RRe-7 & Checking the quality of raw material & & 7 \\
\hline & RRe-8 & Results of checking raw materials & & 6 \\
\hline \multirow{2}{*}{ Delivery } & DR-3 & Quality standards for raw materials & \multirow{2}{*}{2} & 7 \\
\hline & DR-6 & Delivery pass for suppliers & & 7 \\
\hline
\end{tabular}

Sources: Primary Data (2017)

Table 10 shows that the subcriteria (dimensions) for perspective return have 8 yellow dimensions, but are still in the good criteria with weights between 6 and 7. Performance evaluation for perspectives which are at the average level is the same as the study of Surjana et al. (2013) and Ramlan \& Qiang (2014). Likewise for the make perspective subcriteria which has 7 yellow dimensions, but it has a weight between 6 and 7 so it is still critically good. In relation to Figure 2 above there is a difference between the criteria from the perspective of make and this dimension subcategory is caused by different evaluations by respondents when they assess the criteria and subcriteria weights. For example, a respondent considered that the sub-criteria of "Errors in packing raw materials from suppliers" from the perspective criteria make did not affect other subcriteria. The perspective dimensions that are at least yellow because they are dominated by green are the dimensions of the plan and delivery perspective. While the dimensions from the perspective of the source have the most yellow dimensions as many as 7 dimensions. From these 7 dimensions, there is 1 dimension that has a weight of 7 and 2 dimensions weighing 6 . but there are 2 dimensions that have a weight of 5 that are on the average criteria and 2 dimensions which have a weight of 4 approaching the poor category. Therefore, 4 dimensions, i.e. "Cost of ordering raw materials from suppliers", "Availability of raw materials from suppliers", "A daily supply of raw materials for rice from suppliers", and "Payment of raw material for rice to suppliers". The four dimensions must be immediately improved by the company. Because these four dimensions are most important regarding the evaluation of sources of raw materials and financing related to increasing supplier performance.

\section{TRAFFIC LIGHT SYSTEM ANALYSIS ON THE RELATIONSHIP PERFORMANCE OF COMPANY AND SUPPLIER}

The next measurement after conducting the OMAX weighting on five SCOR perspectives is TLS. TLS analysis is used to measure the overall rice supply chain performance. The result of the analysis as in table 11 as follows: 
TABEL 11. TRAFFIC LIGHT SYSTEM RICE SUPPLY CHAIN PERFORMANCE ON SUPPLIER NETWORK PHASE CV. LINTAS INDO COMODITY MANDIRI

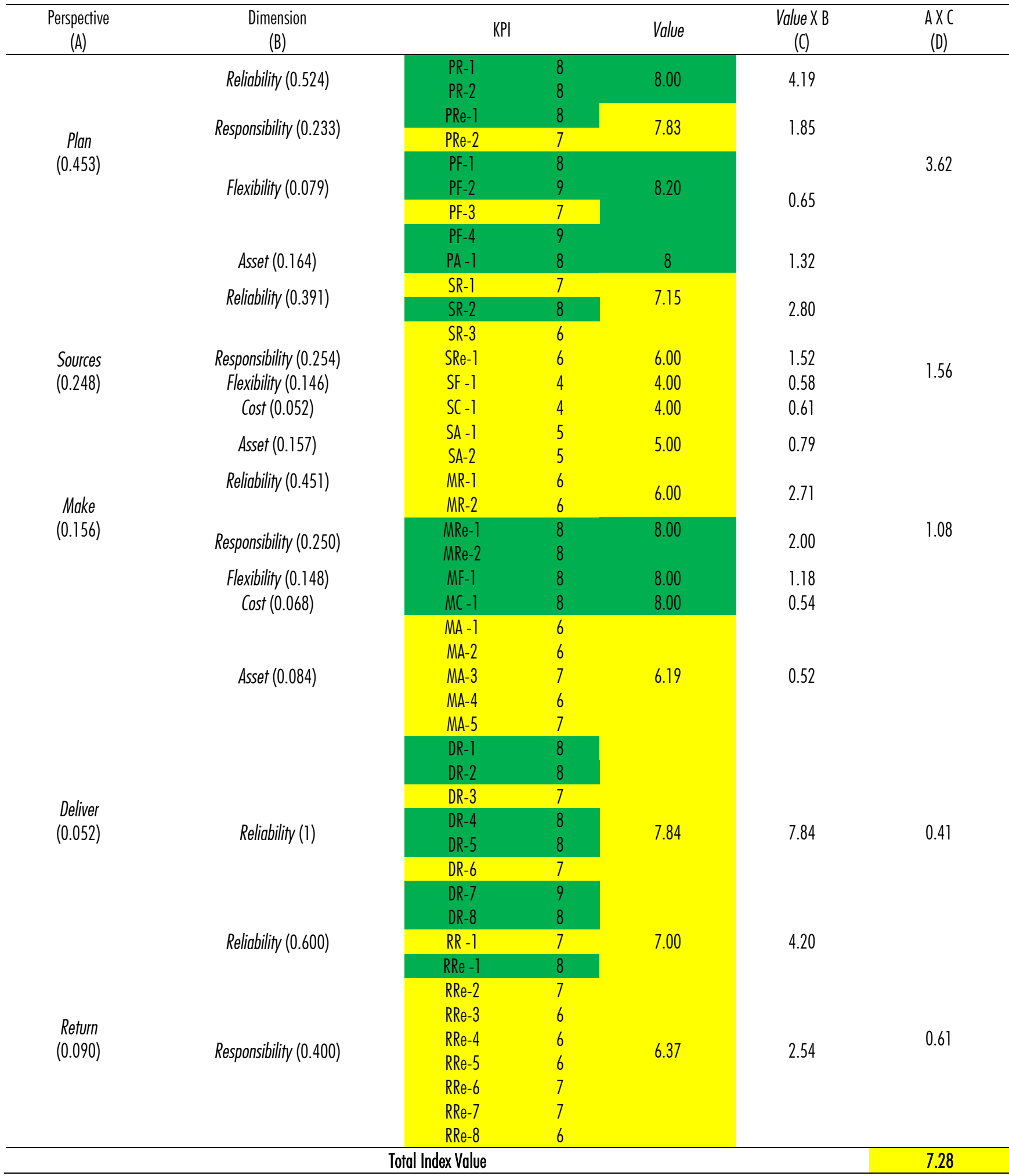

Sources: Primary Data (2017) 
Based on table 11, can be said: First, from the total of $45 \mathrm{KPI}$, not a single KPI is found below the standard, i.e. the red category. From this result, the company can continue the cooperation with the suppliers because the achievement of the result of the performance is satisfactory. Second, $26 \mathrm{KPI}$ is in the yellow category which indicates a medium level of company's performance. Based on the TLS, the total index value is 7.28 in the yellow category. Overall, the KPI has not achieved the expected performance, although the result is close to the pre-determined target. Thus, the management must be cautious about the possibility of performance degradation and there must be continuous improvement of performance.

\section{MANAGERIAL IMPLICATIONS}

The rice supply chain analysis by using SCOR and AHP, OMAX, and TLS show the total index value of 7.28. This result is the overall company performance and relation with the suppliers. The total index value of 7.28 is categorized as the performance is in the achievement of a satisfactory relationship. Therefore, there is no significant obstacle for CV LICM. However, the performance cannot be said to be optimal and effective because it has several indications as follows:

First, the partnership has not been fully formed which means that the partnership from upstream, i.e. farmers, to downstream, i.e. riceindustry companies, have not been fully established in the rice supply chain. Second, CV LICM only establishes a contractual partnership with suppliers to get the raw materials in the rice supply chain. This formal contract is a form of mutually beneficially binding agreement, and it is a formal relationship between the company and suppliers. It is expected that the impact can be felt all the way from the top (the suppliers) to the bottom (the crop farmers).

Therefore, the patterns of supply chain management are determined by the company's business strategy, CV LICM. In terms of a formal partnership, it only happens between the company and the supplier of Tier-3. Meanwhile, the informal partnership only happens in between Supplier of Tier3 and other previous suppliers. It is in line with the descriptive analysis on the mapping of the rice supply chain structure where although the flow in this rice supply chain is smooth, the rice supply chain cannot be said to be effective. So, it obstructs activities related to the rice supply chain. These obstacles generally occur in the following matters: first, the cost of transporting rice is quite high because it tends to have complicated and long-term flow pattern of raw materials. The three rice production centers in South Sumatra are located far enough from CV LICM, such as Banyuasin where the flow pattern of rice raw material is conducted through river and land routes. This condition will affect the transportation cost in transporting the raw materials to the company.

Second, the flow of information distribution in the rice supply chain is less smooth. The flow of information is only smooth between the company and supplier so that the farmers cannot understand for sure that their rice is processed and turned into highquality premium brand namely Selancar by CV LICM.

\section{CONCLUSION}

There are three forms of the flow network in the rice supply chain in which the institution and government are less involved. In this case, the government intervention is needed in order to overcome the farmers' problem after their harvest. Therefore, it is necessary to strengthen the intervention from institutions, government, both KUD and BP3K at the sub-district level, and the departments of agriculture in the regional and provincial levels.

The total index value is 7.28 based on the analysis of SCOR \& AHP, OMAX, and TLS in the rice supply chain performance. This condition reflects the satisfactory achievement of a relationship between the company and the supplier. However, it cannot be said to be optimal or effective because the supply chain partnership has not been formed thoroughly. The farmers are the most vulnerable supply chain players due to the limited flow of information. Therefore, appropriate solutions are required to enable farmers in accessing the market information. 


\section{REFERENCES}

Adiyatna, H., \& Hasibuan, S. (2015) Pemodel Pengelolaan Rantai Pasok Beras dalam Penyelenggaraan Ketahanan Pangan Beras di Tingkat Kabupaten. Proceeding Conference: Seminar Sistem Produksi XI dan Seminar Nasional Manajemen Rekayasa Kualitas VI, January 2015, Bandung. Retrieved from https://www.researchgate.net/.../318108491 Pemodel_Pengelolaan_Rantai_Pasok_Beras.. . [accessed August 2, 2018].

Akyuz, G. A, \& Erkan, T.E. (2010). Supply chain performance measurement: a literature review. International Journal of Production Research, 48(17), 5137-5155, https://doi.org /10.1080/00207540903089536

Anatan, L., \& Ellitan, L. (2008). Supply Chain Management. Bandung: Alfabeta.

Balubaid, M. \& Alamoudi, R. (2015). Application of the Analytical Hierarchy Process (AHP) to MultiCriteria Analysis for Contractor Selection. American Journal of Industrial and Business Management, 5(9), 581-589. https://doi.org/ 10.4236/ajibm.2015.59058

Chopra, S., \& Meindl, P. (2001). Supply Chain Management-Strategy, Planning and Operating. New Jersey: Pretice Hall Inc.

Ervil, R. (2010). Pengembangan Model Pengukuran Kinerja Supply Chain Berbasis Balanced Scorecard (Studi Kasus: PT. Semen Padang). Jurnal Ternologi, 1, 68-77.

Indardi, I. (2016). Pengembangan Model Komunikasi dalam Pemberdayaan Masyarakat Tani (Studi Kasus pada Kelompok Tani Jamur Merang Lestari Makmur di Desa Argorejo, Sedayu, Bantul). AGRARIS: Journal of Agribusiness and Rural Development Research 2(1), 75-86, https://doi.org/0.18196/agr.2128

Indrajit, R. E., \& Richardus, D. (2002). Konsep Manajemen Supply Chain. Jakarta: Gramedia Widiasarana Indonesia.

Kotler, P. (2003). Marketing Management (Eleventh Edi). New Jersey: Prentice Hall Inc.

Mathuramaytha, C. (2011). Supply Chain Collaboration-What's an outcome?: A Theoretical Model. In: International Conference on Financial Management and Economics Proceedings 2011 (pp. 102-108). IACSIT Press, Singapore. Retrieved from www.ipedr.com/vol11/20-R10023.pdf. [accessed May 5, 2018]

Mubyarto. (1991). Pengantar Ekonomi Pertanian. LP3ES, Jakarta.
Nuraini, C., Darwanto, D.H., Masyhuri, \& Jamhari. (2016) Model Kelembagaan pada Agribisnis Padi Organik Kabupaten Tasikmalaya. AGRARIS: Journal of Agribusiness and Rural Development Research, 2(1), 9-16. https://dx. doi.org/10.18196/agr.2121

Pujawan, I. Y. (2005). Supply Chain Management. Surabaya: Guna Widya.

Ramlan, R. \& Qiang, L.W. (2014). An Analytic Hierarchy Process Approach For Supplier Selection: A Case Study. In 3rd International Conference on Global Optimization and Its Application (ICOGOIA 2014), September 9-12, 2014, Yogyakarta. Retrieved from https://core. ac.uk/download/pdf/42956255.pdf. [accessed July 26 2018]

Sarmah, S. P., Acharya, D., \& Gayol, S. K. (2006). Buyer vendor coordination models in supply chain management. European Journal of Operational Research, 175(1), 1-15. https:// doi.org/10.1016/j.ejor.2005.08.006

Sarwono, J. (2006). Metode Penelitian Kuantitatif dan Kualitatif. Yogyakarta: Graha Ilmu.

Sidarto. (2008). Konsep Pengukuran Kinerja Supply Chain Management pada Sistem Manufaktur dengan Model Performance of Activity dan Supply Chain Operation Reference (Studi Kasus: PT. Petrokimia Gresik). Jurnal Teknologi, 1(1), 34-43. jurtek.akprind.ac.id /sites/default/files/hal-68-77-sidarto-gabungok.pdf

Sidik, M., \& Purnomo, S. (1991). Peningkatan Pendapatan Petani di Kabupaten Karawang, Jawa Barat Melalui Identifikasi Saluran Pemasaran. Majalah Pangan 10(III), 44-55, Oktober. Bulog. Jakarta.

Suhardedi, C., Darwanto, D.H., \& Irham, I. (2017). Competitiveness Rice Farming In Sragen Regency. Jurnal Agro Ekonomi, 28(1), 19-31. https://doi.org/10.22146/jae.24584

Sukendar, I., Nurwidiana, \& Hidayati, D.N. 2018. Implementation of supply chain management in supplier performance assessment using Analytical Hierarchy Process (AHP) Objective Matrix (OMAX) and Traffic Light System. MATEC Web of Conferences, 154, 01054 (2018) https://doi.org/10.1051 /matecconf/20 $1815401054 \quad$ [accessed August 10, 2018].

Surjasa, D, Gumbira-Sa'id, E., Arifin, B., \& Jie, F. (2013). Indonesian rice supply chain analysis and supplier selection model. International Journal of Information, Business and Management, 5 (1), 198. https://research 
AGRARIS: Journal of Agribusiness

and Rural Development Research

bank.rmit.edu.au/ view/rmit:21369 (accessed August 10, 2018)

Susanawati, S., Jamhari, J., Masyhuri, M., \& Darwanto, H.D. (2017). Identifikasi Risiko Rantai Pasok Bawang Merah di Kabupaten Nganjuk. AGRARIS: Journal of Agribusiness and Rural Development Research, 3(1), 15-22. https:// doi.org/10.18196/agr.3140

Triyono, Mulyo, J.H., Masyhuri, \& Jamhari. (2016) Pengaruh Karakteristik Struktural dan Manajerial Terhadap Efisiensi Usahatani Padi di Kabupaten Sleman. AGRARIS: Journal of Agribusiness and Rural Development Research, 2(1), 1-8. https://dx.doi.org/10.1 8196/agr.2120

Widodo, A.S. , \& Wulandari, R. (2016). Analisis Pola Konsumsi dan Tingkat Kerawanan Pangan Petani Lahan Kering di Kabupaten Gunungkidul (Studi Kasus di Desa Giritirto, Kecamatan Purwosari, Gunungkidul). AGRARIS: Journal of Agribusiness and Rural Development Research, 2(2), 161-167. https: //doi.org/0.18196/agr.2237

Van der Vorst, J.G.A.J. (2006). Performance Measurement in Agrifood Supply Chain Networks: An Overview. in Wijnands, Huirne \& van Kooten (ed.). Quantifying The AgriFood Supply Chain/ Ondersteijn. Dordrecht: Springer/ Kluwer. 